\title{
Vitrification of rat testicular tissue using biopolymers
}

\author{
N. O. Volkova, M. S. Yukhta, A. M. Goltsev \\ Institute for Problems of Cryobiology and Cryomedicine, NAS of Ukraine \\ 23, Pereyaslavskaya Str., Kharkiv, Ukraine, 61015 \\ volkovana781@gmail.com
}

\begin{abstract}
Aim. To assessof the effect of cryopreservation by vitrification on morphofunctional parameters of immature rat testicular tissue in a cryoprotective media based on polymeric carriers. Methods. Samples of immature rat testicles were rapidly immersed in liquid nitrogen under protection of the cryomedium $1(15 \%$ DMSO $+18 \%$ glycerol $+0.5 \mathrm{M}$ sucrose $)$ or the cryomedium $2(15 \%$ DMSO $+18 \%$ glycerol $+15 \%$ PEO) based on biopolymers (bovine serum albumin (BSA), collagen (CG) or fibrin (FG) gels). The comparison groups included the intact control and fragments vitrified in Hank's solution. Results. In contrast to BSA and CG, FG had a more pronounced protective effect. Its combination with the cryomedium 1 led to a decrease in the degree of retraction and desquamation of spermatogenic epithelium, as well as to a three-fold increase in cell density compared to the negative control. The metabolic activity of testis tissue vitrified under protection of FG and the criomedium 1 increased 2.75 times compared to the negative control (BSA and CG in this cryomedium led to 2.1- and 2.0-fold increase, respectively). A similar trend was observed in the LDH activity. Biopolymers in the cryomedium 2 had a positive effect upon histological examination, but did not contribute to the preservation of metabolic activity of spermatogenic epithelial cells. Conclusion. Cryomedium 1 based on fibrin gel had the optimal properties among all studied combinations of biopolymers and cryoprotectants. The obtained data can be used for development of vitrification methods for human seminiferous tubules.
\end{abstract}

Ke y w or d s: Immature testicular tissue, spermatogenic epitelium, cryoprotective medium, collagen gel, fibrin gel, metabolic activity

\section{Introduction}

Cryopreservation of testicular tissue is a unique technique for fertility preservation in pre-pubertal boys, who do not yet have sperm in the ejaculate and who are scheduled to undergo gonadotoxic treatment [1]. In such cases, the primary purpose of testicular tissue cryopreservation is further autologous transplantation to initiate spermatogenesis [2]. Additionally, the use of spermatozoa obtained by testicular tissue culturing for extracorporal fertilization is considered as a promising approach [3].

(C) 2020 N. O. Volkova et al.; Published by the Institute of Molecular Biology and Genetics, NAS of Ukraine on behalf of Biopolymers and Cell. This is an Open Access article distributed under the terms of the Creative Commons Attribution License (http://creativecommons.org/licenses/by/4.0/), which permits unrestricted reuse, distribution, and reproduction in any medium, provided the original work is properly cited 
Freezing by vitrification is increasingly used at cryopreservation of immature testicular tissue. Vitrification is an effective strategy to prevent the formation of ice crystals due to the use of high concentrations of cryoprotectants and ultra-fast cooling, which minimizes cell damage [4]. Currently, additional components reducing cell damage during cryopreservation are protein impurities. It has been shown [5] that the use of fetal calf serum, bovine serum albumin, recombinant protein in cryoprotective media increases the viability of cells after freezing-thawing. The addition of serum to cryoprotective media has a number of disadvantages: variability in its composition, the possibility of virus contamination and the presence of unwanted biologically active substances. However, in most existing cryopreservation protocols, the testicular tissue uses serum albumin as a protein component [6]. This leads to the search for new, more suitable components to protect biological objects from the freezing stress.

The used method of tissue fragment encapsulation is based on the cell scaffold technology [7]. Biopolymer gels represent an interesting starting material for soft, and lately also for hard tissue regeneration. The latter relies on immobilization of cells in a biomaterial, which allows bidirectional diffusion of nutrients, oxygen, and waste, thus promoting cell interactions. The Substances for encapsulation should also be biocompatible and favor (subject to application) vascular invasion and tissue integration in the host [8].

Biopolymer gels are very often used as scaffolds. They can be degradable or nondegradable. The two main classes of natural biopolymers are proteins and polysaccharides
[9]. Collagens are the most abundant family of the complex enzymatically degradable proteins with unique biological properties. They are involved in forming membranes, fibrillar system and other components of the extracellular matrix, determining structural integrity and physiological functions in cells [10]. The results obtained in the field of cryobiology showed that the distribution of water and structure of ice crystals in collagen gels depend on the composition of the gel and the program of freezing [11]. Thus, the presence of an extracellular matrix may affect the structure of ice formed during freezing-thawing, and hence the final result of cryopreservation.

Now, fibrin gel is widespread as an alternative to collagens. The products derived from autologous blood are used in the regenerative medicine for the recovery of damaged tissues and organs. The important properties of fibrin gel are an ability to degrade in a controllable way and selforganization into a polymer system that mimics blood clotting. At the same time, fibrin gel and other derivatives of blood (serum, plasma) contain a large number of different bioactive substances used as protectors from the damages during the cryopreservation of the cells.

In our preliminary study, it has been shown that the use of fibrin Gel as an integral component of freezing medium is effective and contributes to the preservation of the average density of germinative cell and their metabolic activity during the exposure stage of cryopreservation [12]. The combination of the fibrin gel with $0.7 \mathrm{M}$ glycerol has been found to be the most optimal under cryopreservation using slow non-controlled cooling [13].

The research purpose was to perform a comparative study of the effect of biopolymers 
(bovine serum albumin, collagen and fibrin gel) on morphofunctional characteristics of seminiferous tubules of immature rats after vitrification.

\section{Materials and Methods}

All the manipulations with animals were carried out in accordance with international bioethical norms, legislative documents of Ukraine, statements of the IV European Convention for the Protection of Vertebrate Animals Used for Experimental and Other Scientific Purposes [14] as well as the protocol of the Committee in Bioethics of the Institute for Problems of Cryobiology and Cryomedicine of the National Academy of Sciences of Ukraine (№2014-02). The research was performed in immature male rats $(\mathrm{n}=50)$ weigting $(50 \pm 15) \mathrm{g}$ at the age of 7-8 weeks [15] according to the scheme (Fig. 1).

Cryoprotective solutions were ex tempore prepared on the basis of biopolymer solutions:

1) bovine serum albumin (BSA) (PAA, Austria), which was used at a concentration of $50 \mathrm{~g} / \mathrm{L}$ in Hank's solution (PAA);

2) collagen gel (CG), which was obtained from the tendon of rat tails according to the standard procedure [16]. The $\mathrm{pH}$ level was

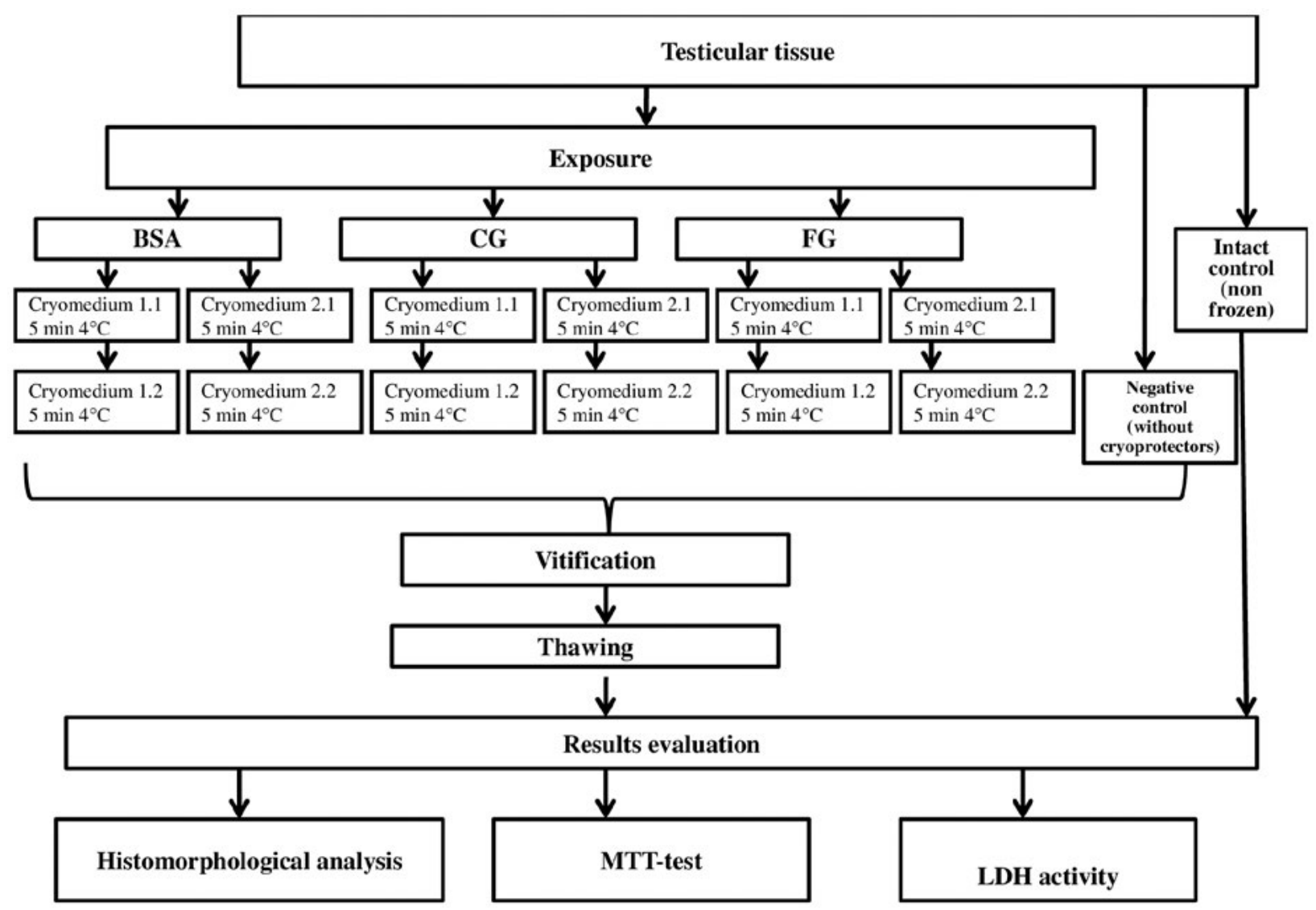

Fig. 1. The scheme of experiment 
adjusted to neutral using $0.34 \mathrm{~N} \mathrm{NaOH}$ solution;

3) fibrin gel (FG), which was isolated from fresh blood of animals, procured from a cardiac vein in a volume of 5-7 $\mathrm{ml}$ and centrifuged for $12 \mathrm{~min}$ at a rate of $1500 \mathrm{~g}$. After centrifugation, three fractions of blood were received: lower - erythrocyte mass; upper platelet-pure plasma; medium - fibrin gel enriched with thrombocytes.

The following media were prepared based on this biopolymers:

Cryomedium 1: 1.1 - biopolymer (5\% $\mathrm{BSA}, \mathrm{FG}$ or $\mathrm{CG})+5 \% \mathrm{DMSO}+6 \%$ glycerol $+0.1 \mathrm{M}$ sucrose; samples exposition for 5 min at $4^{\circ} \mathrm{C}$;

1.2 - biopolymer (5\% BSA, FG or CG) + $15 \% \mathrm{DMSO}+18 \%$ glycerol $+0.5 \mathrm{M}$ sucrose; exposition for $5 \mathrm{~min}$ at $4^{\circ} \mathrm{C}$.

Cryomedium 2: 2.1 - biopolymer (5\% $\mathrm{BSA}, \mathrm{FG}$ or $\mathrm{CG})+5 \% \mathrm{DMSO}+6 \%$ glycerol $+5 \%$ PEO; exposition for $5 \mathrm{~min}$ at $4{ }^{\circ} \mathrm{C}$.

2.2 - biopolymer (5\% BSA, FG or CG) + $15 \%$ DMSO + $18 \%$ glycerol + $15 \%$ PEO; exposition 5 min under $4{ }^{\circ} \mathrm{C}$ exposition for 5 min at $4^{\circ} \mathrm{C}$.

The samples of the rat testicles of size 2-3 $\mathrm{mm}^{3}$ were obtained mechanically and incubated sequentially in each variant of cryomedium 1 and 2 for 5 minutes at $4{ }^{\circ} \mathrm{C}$ and then cryopreserved by vitrification (rapid immersion in liquid nitrogen). The warming was carried out by successive transfer of samples to a sucrose solution of a decreasing concentration $(1 \mathrm{M}, 0.5 \mathrm{M}, 0.25 \mathrm{M}, 0 \mathrm{M})$ at temperature of $42^{\circ} \mathrm{C}$. The incubation in each medium lasted 5 minutes.

The comparison groups: intact control (freshly isolated fragments of seminiferous tubules of rats) and negative control (fragments of rat seminiferous tubules, cryopreserved in Hank's solution). Biopolymers (5 \% BSA, FG or CG) without cryoprotectants also served as a control.

Histomorphological experiments were carried out maintaining blinding by involving the third person who did not take part in the experiment. Paraffin blocks were prepared and slices of $7 \mu \mathrm{m}$ thickness were stained by hematoxylin and eosin. Histological preparations were studied using Axio Observer Z1 inverted microscope (Carl Zeiss, Germany) including the following criteria: cell retraction, nuclei condensation, epithelium detachment, and formation of gaps [17]. The image files obtained in such a way were processed using the Axiovision v. 4.8 (Carl Zeiss). An average cell density of spermatogenic epithelium (the number of nuclei per the area unit) was detected.

To determine the total metabolic activity testicular tissue samples (3 fragments weighing $75 \pm 3 \mathrm{mg}$ ), the MTT test was used. Briefly, MTT 3-(4,5-dimethylthi azol-2-yl)-2,5-diphenyltetrazolium bromide (Fluka, Germany) of final concentration of $0.5 \mathrm{mg} / \mathrm{mL}$ was added to the samples and incubated for $3 \mathrm{~h}$ at $37^{\circ} \mathrm{C}$; the medium was removed and $100 \%$ DMSO was added to each tissue sample to solubilize the precipitate [18]. Absorbance was read at $540 \mathrm{~nm}$. Obtained data were normalized to $\mathrm{mg}$ of tissue.

The total LDH activity was quantified by UV spectrophotometry using test kits (Randox, United Kingdom). The samples of tissues of all experimental groups were homogenized and filtered, with following centrifugation (1000xg for $10 \mathrm{~min}$ ). The reaction was started by addition of the enzyme sample to $20 \mu \mathrm{L}$ of super- 
natant of tissue homogenat followed by spectrophotometrical measuring of a decrease in absorbance of NADH at $365 \mathrm{~nm}$, according to the manufacturer's instructions.

Kruskal-Wallis ANOVA test and multiple comparisons $p$ values were applied to compare the difference between the groups using Statistics 8 (StatSoft, USA) software.

\section{Results and Discussion}

The MTT-test results are shown in Figure 2. Noteworthy, vitrification in investigated biopolimers did not lead to a significant change in metabolic activity of the immature testis tissue compared to negative control but it increased in the groups with biopolymers and cryomedium 1 or 2 . At the same time, the cryomedium 1 was more effective than cryomedium 2. Metabolic activity of seminiferous tubules vitrified with BSA or CG in combination with the studied cryoprotective media exceeded the negative control but the results did not differ significantly. The best results were obtained in the samples cryopreserved under protection of FG-based cryomedium 1 if compared to other biopolymers. This parameter increased 1.83 times relative to the corresponding control (FG). However, in all examined samples, the metabolic activity of cells after vitrification remained significantly lower than intact control.

The total LDH activity in all investigated samples of seminiferous tubules of immature rat testes after vitrification was higher than negative control (Fig. 3). This index was the highest in the group of cryomedium 1 with $\mathrm{CG}$ or FG application (it exceeded the negative control 4.2 and 3.8 times respectively) though there is no significant difference between these biopolymers. Compared to the intact control LDH activity for all vitrified specimens was considerably lower.

Thus, an analysis of the obtained data indicates that the level of metabolic activity de-

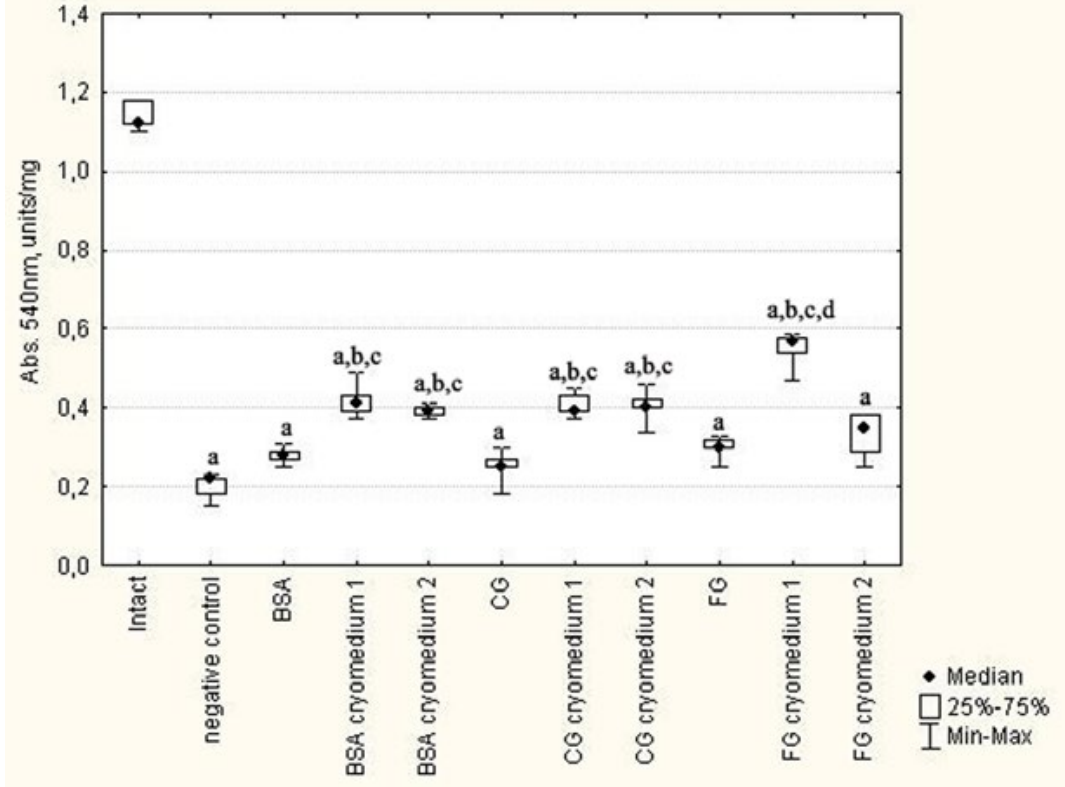

Fig. 2. Metabolic activity (MTT test) of seminiferous tubules of immature rat testes after vitrification in investigated media. The difference is statistically significant relative to: ${ }^{\mathrm{a}} \mathrm{-}$ intact group; $b$ - negative control; ${ }^{c}$ corresponding control, d - corresponding cryomedium based on BSA/CG $(\mathrm{p}<0.05)$, according to the Kruskal-Wallis test. 


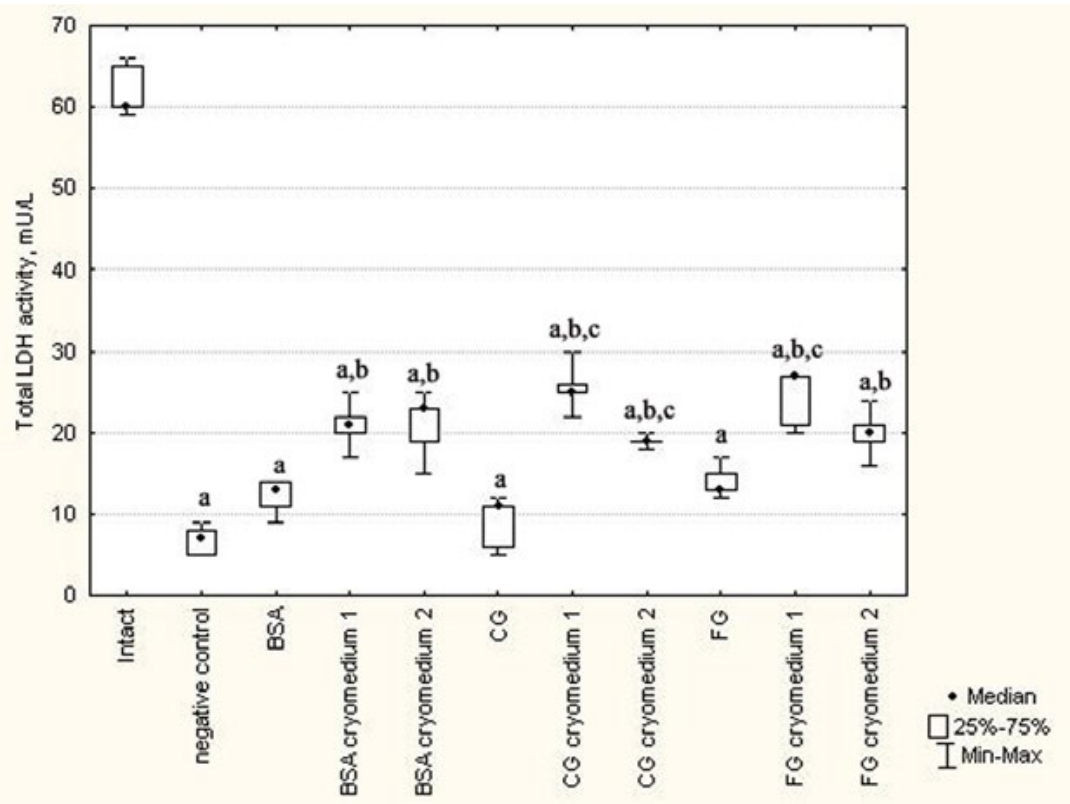

Fig. 3. Total LDH activity of seminiferous tubules of immature rat testes after vitrification in investigated media. The difference is statistically significant relative to: a - intact group; ${ }^{\mathrm{b}}$ - negative control; ${ }^{\mathrm{c}}-$ corresponding control $(\mathrm{p}<0.05)$, according to the Kruskal-Wallis test. creased in the samples of the seminiferous tubules of the testes of immature rats after the vitrification-thawing procedure, and the using of combination of biopolimer and cryomedium softens a freezing stress.

The results of histological study showed that seminiferous tubules of intact immature

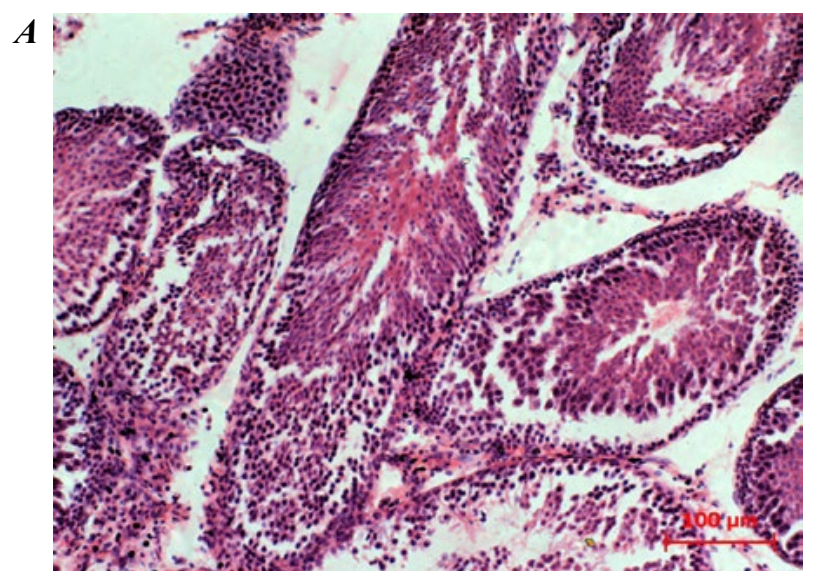

rats had a normal structural organization (Fig. 4 A). Vitrification in Hank's solution (negative control) caused gross structural abnormalities: sharp retraction with the formation of large cracks inside spermatogenic epithelium, its total desquamation, lysis and pycnosis in almost $90 \%$ of the cell nuclei (Fig. 4 B).

Fig. 4. Seminiferous tubules of immature rat testes. $A$ - intact control, $B$ - negative control. Hematoxylin and eosin staining.

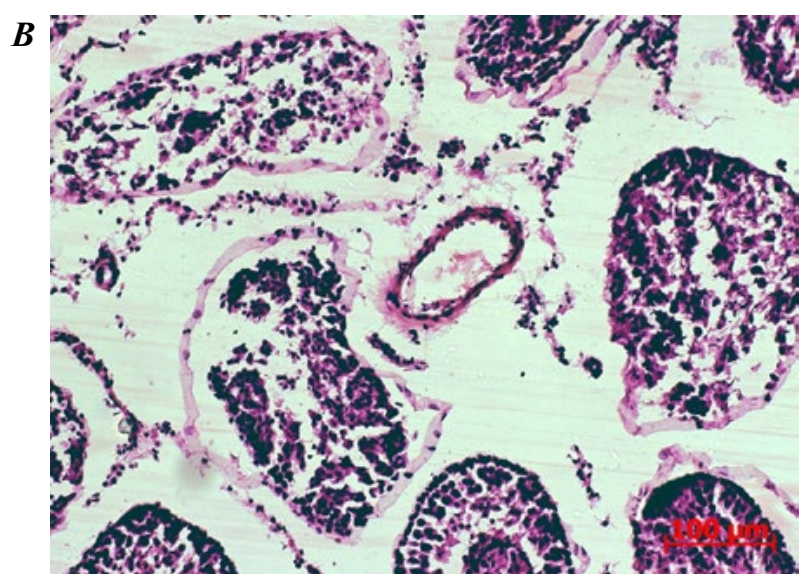


Biopolymers without cryoprotectants were proved to be ineffective and to cause gross damages as in the negative control (Fig. 5 BSA, CG, FG). The structure of seminiferous tubules vitrified in cryomedium 1 based on BSA and CG was characterized by lower retraction and desquamation of spermatogenic cells compared to negative control while maintaining a high frequency of pycnosis and lysis of nuclei (Fig. 5 BSA, CG cryomedium 1). The combination of cryomedium 1 with FG was more effective: the spermatogenic epithelium generally retained its histological structure, except for a slight retraction of cells and the presence of individual cells with vacuolated nuclei, diffusely settled throughout the thickness of the epithelial layer (Fig. 5 FG cryomedium 1).

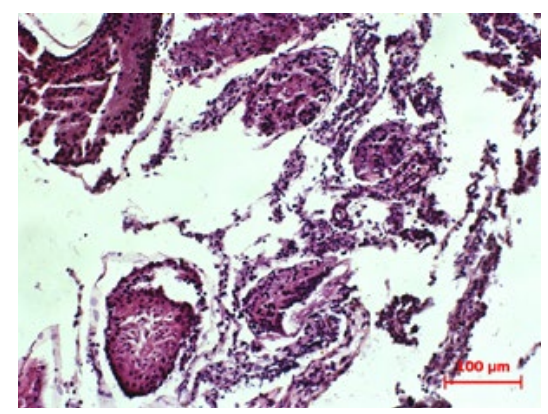

BSA

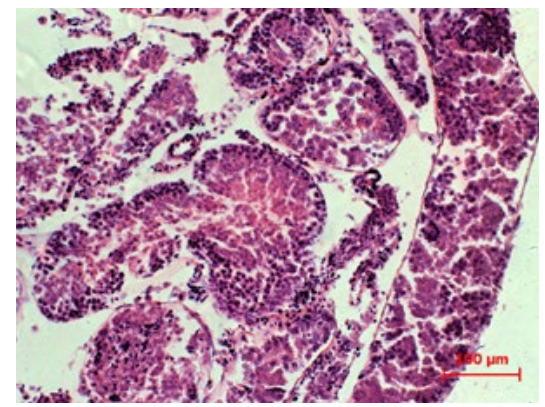

CG

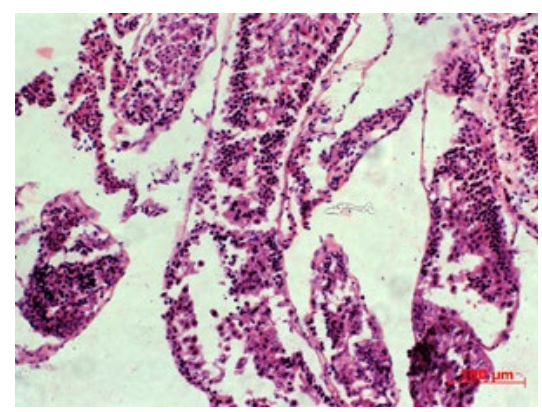

FG

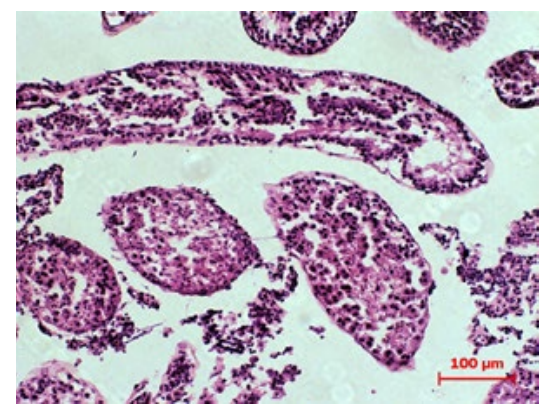

BSA cryomedium 1

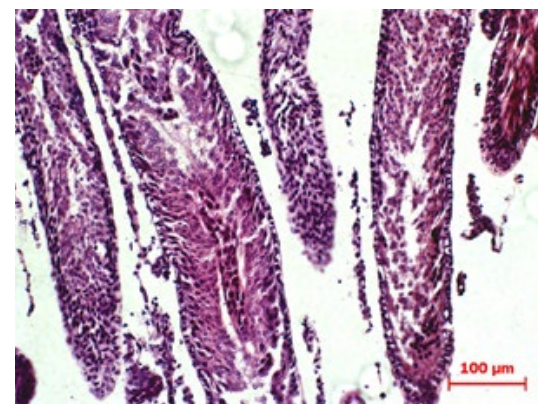

CG cryomedium 1

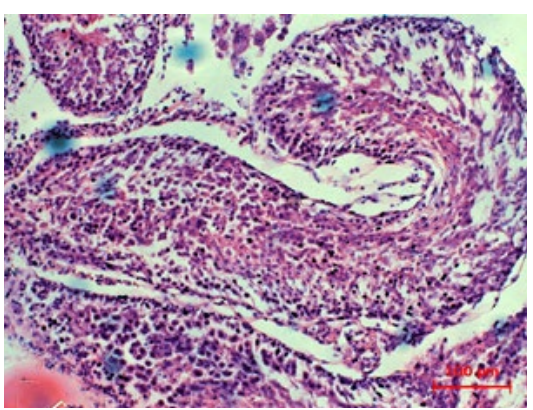

FG cryomedium 1

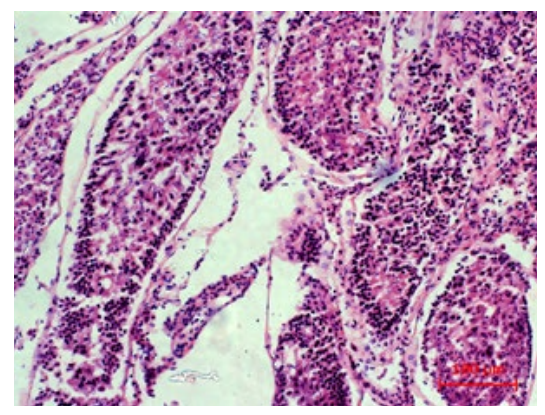

BSA cryomedium 2

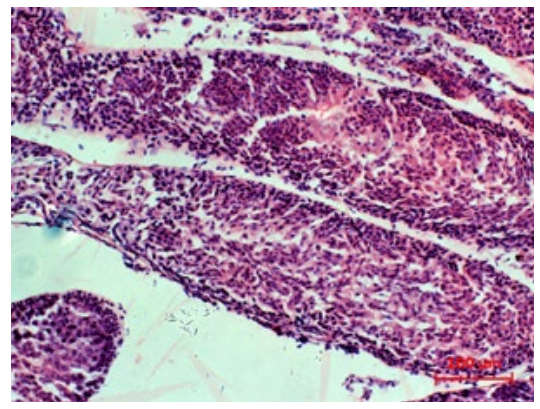

CG cryomedium 2

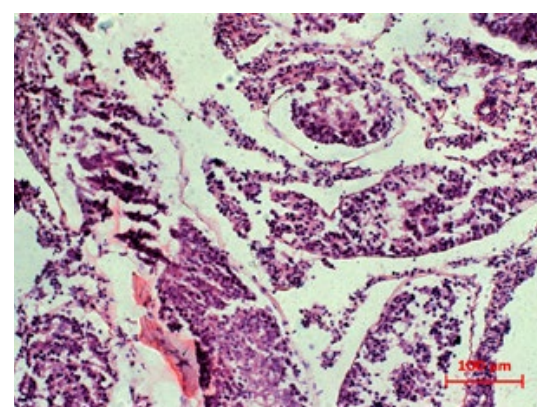

FG cryomedium 2

Fig. 5. Seminiferous tubules of immature rat testes after vitrification. Hematoxylin and eosin staining. 
If compare the group of BSA-based cryomedium 2 with negative control, the degree of retraction decreased and, as a result, necrosis and total cell desquamation came to the fore (Fig.5 BSA cryomedium 2). The histological picture after vitrification in CG with cryomedium 2 was characterized by a slight retraction of germinogenic cells, lack of desquamation but hyperchromic, swollen nuclei of cells were often detected, which prevented a clear definition of spermatogenic epithelium zonation (Fig. 5 CG cryomedium 2). The combination of cryomedium 2 and FG had insufficient cryoprotective action and caused gross structural damages (Fig. 5 FG cryomedium 2).

The average cell density of spermatogenic epithelium after vitrification (Fig. 6) in solutions of biopolymers sharply decreased relatively to the intact tissue and did not significantly differ from the negative control values. The addition of cryoprotectors allowed significant reducing of cell damage during the vitrification-warming process. The maximum effect (a 3-fold increase versus negative control) was observed when using FG-based cryomedium 1. However, even in this case the investigated indicator remained significantly lower than the intact control.

The cell density in this group was significantly higher than after vitrification in a cryomedium 1 based on BSA or CG but did not reach the rate of intact control.

The analysis of the data shows that the metabolic activity after vitrification-thawing in all samples of seminiferous tubules of immature rats vitrified under protection of cryomedia decreased if compared to intact control, but significantly exceeded the value of the negative control. Noteworthy, the use of FG in combination with cryomedium 1 was the most optimal among all the studied combinations of biopolymers and cryoprotectants. In this case, the degree of retraction and desquamation of the spermatogenic epithelium decreased in com-

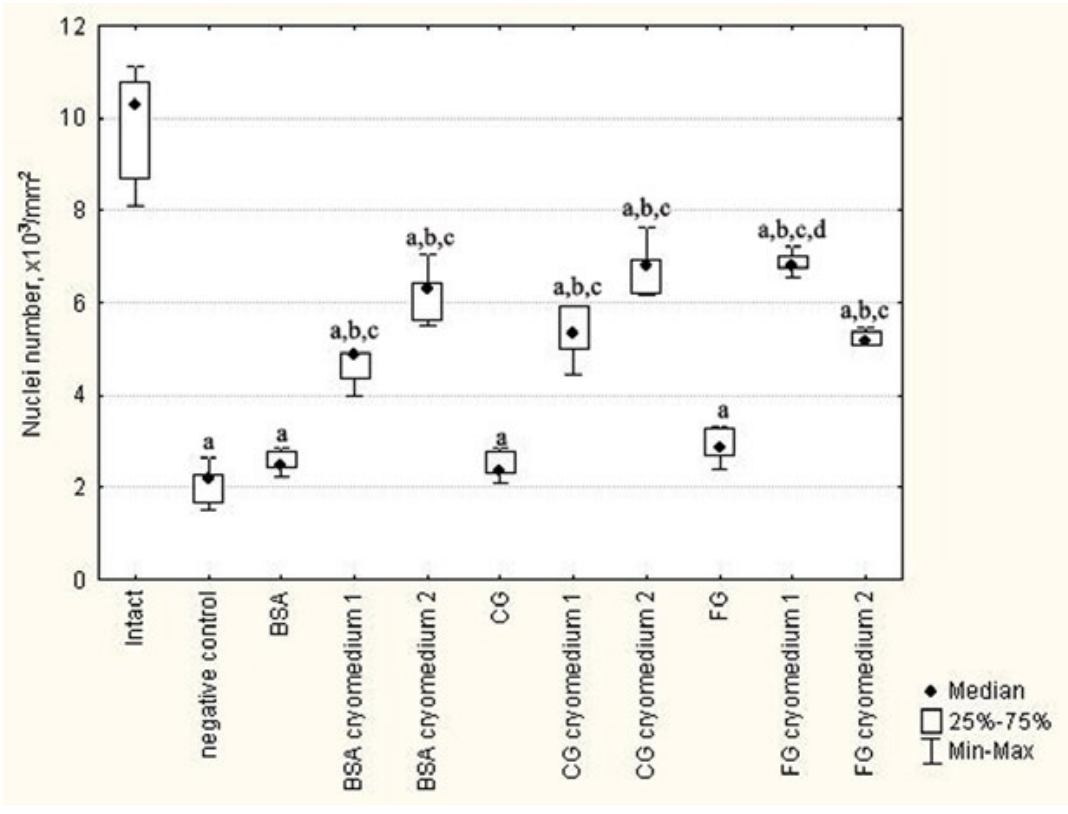

Fig. 6. The average cell density of spermatogenic epithelium after vitrification. The difference is statistically significant relative to: ${ }^{\mathrm{a}}$ - intact group; ${ }^{b}$ - negative control; ${ }^{c}-$ corresponding control, d - corresponding cryomedium based on BSA/CG $(\mathrm{p}<0.05)$, according to the KruskalWallis test. 
parison to the combination with BSA. Unlike collagen, the fibrin gel provided a more pronounced protective effect, which was also manifested in reducing the number of necrotic cells in the spermatogenic epithelium. According to the results of the MTT test, the combined use of FG with cryomedium 1 provided the highest preservation of metabolic activity of the seminiferous tubule cells of immature rats among all investigated variants of the media. A similar tendency was observed regarding the level of total activity of LDH.

Innovative biomaterials have significantly contributed to the development of reproductive medicine, especially in the aspect of fertility maintaining. For example, the FG, because of its biological nature, provides an optimal support for adhesion, proliferation, differentiation and biochemical signaling of cells. It is used for encapsulation of the fragments of integral tissue or single cells to support their 3D structure, as well as to study biological phenomena which is impossible in 2D systems [19]. Noteworthy, FG can be mixed with different growth and angiogenesis factors that can be released in a controlled way to stimulate neoangiogenesis and reduce hypoxic lesions in nonvascular transplants. The results of in vitro experiments showed that FG had a slight inhibitory effect on proliferation of fibroblasts and stimulated the collagen synthesis [20]. Based on the results presented in this paper, it can be stated that FG can also be used as a basis of multicomponent cryoprotective media for vitrification of fragments of seminiferous tubule of immature rats instead of the traditional BSA solution. A prerequisite for ensuring the effectiveness of cryopreservation in this case is the presence of cryoprotectant compositions. Previously, it was shown that the high molecular weight polymers exhibited high cohesive properties, and therefore have a protective impact on biological objects, reducing the extracellular salt concentrations similar to low molecular weight cryoprotectants. The authors noted that the cryoprotective efficiency of polymers consisted in their ability to change the physical properties of solutions during cooling, but not to directly protect and change the characteristics of the cell membrane. We can assume that our findings are explained by the fact that high viscosity of the investigated gels contributed to partial (or complete) vitrification of an extracellular medium in the samples during cooling. Additionally, it is known that one of the features of biopolymer solutions is their high viscosity, reciprocally dependent on temperature. Therefore, biopolymers gels can affect the crystal formation, contributing to the appearance of smaller ice crystals and thus reducing its mechanical action on biological objects. Such a property of gels is stipulated with an increase in the viscosity of the medium, which impedes the intensive formation of crystallization nuclei and inhibits the growth of ice crystals in volume. In general, the obtained results allow us to think about the perspectives in using a combination of FG and cryomedium 1 in the protocol for vitrification of the seminiferous tubules.

\section{Conclusions}

Based on the results of the analysis of total activity of LDH, MTT test and histomophometry, it was found that the best of all the examined biopolymers was fibrin gel with the combination of cryoprotectors (DMSO, glycerol, sucrose). The obtained data can be used for substantiation and development of effective 
cryopreservation methods for human seminiferous tubules using biopolymers.

\section{REFERENCES}

1. Keros V, Hultenby $K$, Borgstrom B, Fridstrom $M$, Jahnukainen K, Hovatta O. Methods of cryopreservation of testicular tissue with viable spermatogonia in pre-pubertal boys undergoing gonadotoxic cancer treatment. Human Reproduction. 2007;22 (5):1384-95.

2. Stukenborg JB, Jahnukainen K, Hutka M, Mitchell RT. Cancer treatment in childhood and testicular function: the importance of the somatic environment. Endocrine connections. 2018; 7(2): R69-87.

3. Ginsburg ES, Yanushpolsky EH, Jackson KV. In vitro fertilization for cancer patients and survivors. Fertility and Sterility. 2001; 75(4): 705-10.

4. Poels J, Langendonckt A, Many MC, Wese FX, Wyns $C$. Vitrification preserves proliferation capacity in human spermatogonia. Hum Reprod. 2013;28(3): 578-589.

5. Dimasi L. Meeting increased demands on cell-based processes by using defined media supplements. BioProcess International. 2011;9(8):48-58.

6. Keros V, Rosenlund B, Hultenby K, Aghajanova L, Levkov L, Hovatta O. Optimizing cryopreservation of human testicular tissue: comparison of protocols with glycerol, propanediol and dimethylsulphoxide as cryoprotectants. Hum Reprod. 2005;20(6):1676-1687.

7. Nicodemus GD, Bryant SJ. Cell encapsulation in biodegradable hydrogels for tissue engineering applications. Tissue Eng Part B Rewires. 2008; 4:149-65.

8. Jafari M, Paknejad Z, Rad MR, Motamedian SR, Eghbal MJ, Nadjmi N, Khojasteh A. Polymeric scaffolds in tissue engineering: a literature review. J Biomed Mater Res B. 2017;105(2):431-59.

9. Guarino V, Ambrosio L. Properties of biomedical foams for tissue engineering applications. In: Netti PA (ed.) Biomedical foams for tissue engineering applications. - Woodhead Publishing, Cambridge, 2014; pp 40-70.

10. Gelse K, Posch E, Aigner T. Collagens - structure, function, and biosynthesis. Adv Drug Deliv Rev. 2003; 55(12):1531-46.
11. Allenspach $A L$, Kraemer $T G$. Ice crystal patterns in artificialgels of extracellular matrix molecules after quickfreezing and freeze-substitution. Cryobiology. 1989; 26: 170-9.

12. Volkova N, Yukhta M, Goltsev A. Biopolymer gels as a basis of cryoprotective medium for testicular tissue of rats. Cell and tissue banking. 2018; 19(4), 819-26.

13. Volkova NO, Yukhta MS, Chernyshenko LG, Stepanyuk LV, Sokil LV, Goltsev AM. Cryopreservation of Rat Seminiferous Tubules Using Biopolymers and Slow Non-Controlled Rate Cooling. Problems of Cryobiology and Cryomedicine. 2018; 28(4): 278-92.

14. European Convention for the Protection of Vertebrate Animals used for Experimental and Other Scientifi c Purposes. European Treaty Series No. 123 Strasbourg, 18.III.1986. Strasbourg: Council of Europe; 1986. 53p.

15. Campion SN, Carvallo FR, Chapin RE, Nowland WS, Beauchamp D, Jamon R, Koitz R, Winton TR, Cappon GD, Hurtt ME. Comparative assessment of the timing of sexual maturation in male Wistar Han and Sprague-Dawley rats. Reprod Toxicol. 2013; 38(7): 16-24.

16. Chandrakasan G, Torchia DA, Piez KA. Preparation of intact monomeric collagen from rat tail tendon and skin and the structure of the nonhelical ends in solution. J Biol Chem. 1976; 251: 6062-7.

17. Milazzo JP, Vaudreuil L, Cauliez B, Gruel E, Masse L, Mousset-Simeon N, Mace B, Rives N. Comparison of conditions for cryopreservation of testicular tissue fromimmature mice. Hum Reprod. 2008; 23: 17-28.

18. Mossman T. Rapid colorimetric assay for cellular growth and survival: application to proliferation and cytotoxicity assays. J Immunol Methods. 1983; 65(1-2): 55-63.

19. Chiti MC, Dolmans MM, Donnez J, Amorim CA. Fibrin inreproductive tissue engineering: a review on its application as a biomaterial for fertility preservation. Annals of biomedical engineering. 2017; 45(7): 1650-63.

20. Miyamoto Y, Enosawa S, Takeuchi T, Takezawa T. Cryopreservation in situ of cell monolayers on collagen vitrigel membrane culture substrata: ready- 
to-use preparation of primary hepatocytesand ES cells. Cell Transplant. 2009; 18(5): 619-26.

\section{Вітрифікація тканини ясчка щурів з використанням біополімерів}

\section{Н. О. Волкова, М. С. Юхта, А. М. Гольцев}

Мета. Проведення порівняльної оцінки впливу кріоконсервування шляхом вітрифікації на морфофункціональні характеристики незрілої тканини яєчок щурів під захистом кріосередовищ на основі біополімерних гелів. Методи. Зразки яєчок статевонезрілих щурів були швидко занурені в рідкий азот під захистом кріосередовища 1 (15\% ДМСО + $18 \%$ гліцерин + 0,5 М сахароза) або кріосередовища 2 (15\% ДМСО + $18 \%$ гліцерин + $15 \%$ ПЕО) на основі біополімерів (бичачий сироватковий альбумін (БСА), колагеновий (КГ) або фібриновий (ФГ) гель). Групи порівняння: інтактний контроль і фрагменти, вітрифіковані в розчині Хенкса. Результати. На відміну від БСА та КГ, ФГ мав більш виражений протекторний ефект. Його поєднання 3 кріосередовищем 1 призвело до зниження ступеня ретракції та десквамації сперматогенного епітелію, а також до збільшення щільності клітин у ньому в 3 рази порівняно з негативним контролем. За даними МТТ-тесту метаболічна активність тканин яєчка, вітрифікованих під захистом ФГ та кріосередовища 1 , зросла в 2,75 рази порівняно з негативним контролем (БСА та КГ $з$ цим кріосередовищем - в 2,1 та 2,0 рази відповідно). Аналогічна тенденція спостерігалася при дослідженні активності ЛДГ. Біополімери з кріосередовищем 2 мали позитивний ефект при гістологічному дослідженні, але не сприяли збереженню метаболічної активності клітин сперматогенного епітелію. Висновок. Кріосередовище 1 на основі фібринового гелю виявилося найбільш оптимальним серед усіх вивчених комбінацій біополімерів і кріопротекторів. Отримані дані можуть бути використані для обгрунтування і розробки ефективних методів вітрифікації сім'яних канальців людини з використанням біополімерів.

К л ю ч о в і с с о в а: незріла тканина яєчка, сперматогенний епітелій, кріозахисне середовище, колагеновий гель, фібриновий гель, метаболічна активність.

\section{Витрификация ткани яичка крыс с использованием биополимеров}

\author{
Н. А. Волкова, М. С. Юхта, А. Н. Гольцев
}

Цель. Провести сравнительную оценку влияния криоконсервирования путем витрификации на морфофункциональные характеристики незрелой ткани яичек крыс под защитой криосред на основе биополимерных гелей. Методы. Образцы яичек неполовозрелых крыс были быстро погружены в жидкий азот под защитой криосреды 1 (15\% ДМСО + $18 \%$ глицерин $+0,5 \mathrm{M}$ сахароза) или криосреды 2 (15\% ДМСО + 18 \% глицерин $+15 \%$ ПЭО) на основе биополимеров (бычий сывороточный альбумин (БСА), коллагеновый (КГ) или фибриновый (ФГ) гель). Группы сравнения: интактный контроль и фрагменты, витрифицированные в растворе Хенкса. Результаты. В отличие от БСА и КГ, ФГ имел более выраженный защитный эффект. Его сочетание с криосредой 1 приводило к снижению степени ретракции и десквамации сперматогенного эпителия, а также к увеличению плотности клеток в нем в 3 раза по сравнению с отрицательным контролем. По данным МТТ-теста метаболическая активность тканей яичка, витрифицированных под защитой ФГ и криосреды 1 , выросла в 2,75 раза по сравнению с отрицательным контролем (БСА и КГ с этой криосредой - в 2,1 и 2,0 раза соответственно). Аналогичная тенденция наблюдалась при исследовании активности ЛДГ. Биополимеры с криосредой 2 имели положительный эффект при гистологическом исследовании, но не способствовали сохранению метаболической активности клеток сперматогенного эпителия. Заключение. Криосреда 1 на основе фибринового геля оказалась наиболее оптимальной среди всех изученных комбинаций биополимеров и криопротекторов. Полученные данные могут быть использованы для обоснования и разработки эффективных методов витрифицирования семенных канальцев человека с использованием биополимеров.

К л ю ч е в ы е с л о в а: незрелая ткань яичка, сперматогенный эпителий, криозащитная среда, коллагеновый гель, фибриновый гель, метаболическая активность.

Received 08.04.2019 